\title{
Diagnosing MERS-CoV using dempster-shafer method
}

\author{
Memen Akbar, Fandy Hidayat, Wenda Novayani \\ Department of Information Technology, Politeknik Caltex Riau, Indonesia
}

\section{Article Info}

Article history:

Received May 27, 2019

Revised Nov 13, 2019

Accepted Jan 12, 2020

\section{Keywords:}

Dempster-shafer

Expert system

Hajj and umrah

MERS-CoV

\begin{abstract}
MERS-CoV (Middle East Respiratory Syndrome-Coronavirus) is a respiratory syndrome disease caused by the coronavirus which attacks the respiratory tract from mild to severe. MERS-CoV was first reported in Saudi Arabia; total cases of MERS-CoV have continued to increase. In Indonesia, the MERS-CoV enters through the pilgrimage of Hajj and Umrah. But not many people know about this disease and its symptoms. For this reason, an expert system was developed to diagnose MERS-CoV using the DempsterShafer method. The system can detect the disease from the symptoms inputted by user. The output of the system is the value of the probability of the disease, the level of the disease and the suggested. The levels of the disease are Stage 1, Stage 2, and Stage 3 where each has a different treatment based on the level of the disease. The system contains information about MERS-CoV in the form of videos and text. The system was built using the PHP programming language. The testing result shows that all system functionalities have been fulfilled. The expert validation testing had obtained at $76.7 \%$, which prove that the system is good enough in diagnosing MERS$\mathrm{CoV}$ and the results obtained from the questionnaire is at an average of $84.13 \%$ which is very good in helping users in diagnosing disease. The expert system that has been developed can help people in diagnosing the disease before consulting with a doctor.
\end{abstract}

This is an open access article under the CC BY-SA license.

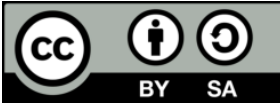

\section{Corresponding Author:}

Memen Akbar

Department of Information Technology, Politeknik Caltex Riau

Jl. Umban Sari No. 1 Rumbai, Pekanbaru - Riau 28265, Indonesia

Email: memen@pcr.ac.id

\section{INTRODUCTION}

In 2012, Middle East Respiratory Syndrome-Coronavirus (MERS-CoV) for the first time reported in Saudi Arabia. After Saudi Arabia, 27 other countries reported MERS cases in their country including Aljazair, Austria, Bahrain, China, Egypt, and another countries. From 2012 to 2018, there are 2.144 MERS$\mathrm{CoV}$ cases reported included 750 death [1]. In Indonesia MERS-CoV coming from Hajj and Umrah pilgrims. In 25 August 2014 many people who went to Hajj and Umrah were infected with the virus, 136 suspects come from 20 provinces, such as West Sumatra, Riau, Jambi, West Java, DKI Jakarta, Bali, and other provinces. There are two Indonesian positively infected MERS-CoV and in the same year, one of them died.

Indonesia is one of the countries that had the largest Umrah pilgrims in the world. The interest of Indonesian in going Umrah increased every year. According to the ministry of religious affair, Indonesia had the third-largest Umrah pilgrim in the world with approximately 699.6 thousand people in 2016; an increase of about 7,2 percent from the previous year [2]. From the data, the possibility of the people infected with MERS-CoV is really high, this is evidenced by the increasing number of people who went on Hajj and Umrah. 
Based on the result of the interview with Dr. Azizman Saad, Sp.P(K), FISR, obtained an information that currently many people do not know about MERS-CoV symptoms because the disease is similar to severe flu. All this time, people are not aware of MERS-CoV symptoms. People are also reluctant to see a doctor when they are sick after returning from Umrah or Hajj due to limited costs and time. The handling becomes late and can lead to death.

Based on the problems, an expert system for diagnosing MERS-CoV is needed. The expert system stores human knowledge so that the computer can resolve existing problems as experts do [3]. An expert system is another alternative to diagnose MERS-CoV without having direct consultation with the doctor and lab check. Dr. Azizman Saad, Sp. P (K), FISR also stated that the system helps a person in diagnosing MERS-CoV before consulting with a doctor.

The expert system is built to diagnose MERS-CoV. In this case, the expert system used the Dempster-Shafer method. Dempster-Shafer method is chosen based on the study of literature belongs to [4, 5] which stated that the technique is more appropriately applied in diagnosing disease. This method is used to find the proofs based on belief function and plausible reasoning used by combining separate pieces of information (evidence) to calculate the possibility of a disruption. Next section of this paper discusses about literature review that consist of previous studies and some of information about MERS-CoV and DempsterShafer. System design, the implementation in source code, and the testing will be explained in Section 3 and 4.

\section{LITERATURE REVIEW}

\subsection{Previous Studies}

Research conducted by Istiqomah (2013) designed an expert system for diagnosing diseases of the gastrointestinal tract using the Dempster-Shafer method [4]. The system is a desktop-based application where the user selects the perceived symptoms and the system shows the results name of the disease, the probability, and the suggested treatment to users. The other earlier research conducted by Kusuma (2015) designed an expert system that performed lung disease diagnosis using Case-Based Reasoning method [6]. The system is also a desktop-based application where the user selects the perceived symptoms and the output is the name of the disease, probability, causes, and suggested treatment to users. Research conducted by Lesmana (2015) designed an expert system for the diagnosis of patients infected with MERS-CoV [7]. This system is a web-based application using forward chaining algorithm. The output of the system results in the form of the disease name and suggested treatment provided to users.

Research conducted by Marlina (2017) designed an application of respiratory diseases diagnosis expert system- speech recognition based using Naive Bayes Classifier [8]. The system is a mobile-based application which the user speaks to a mobile phone to detect the disease. The output of this system is the name of the disease and the probability. Research conducted by Badriyah (2017) designed an expert system to diagnose lung diseases using Certainty Factor method in public health Citangkil [9]. The system is webbased application where the user would choose the symptoms they have. The output of this system is the name of the desease, probability, and the suggested treatment. Several studies address the specifics of MERSCoV disease. Research conducted by Yong (2015) discusses the mathematical model of the spread of MERSCoV in Indonesia [10]. The study conducted by Zang (2014) discussed the strategy of developing vaccines to patients [11]. The study conducted by Momattin (2013) discussed the therapy that MERS-CoV patients should perform [12]. Meanwhile, a study conducted by Djoge (2018) made an application design to diagnose MERSCoV disease which was applied to PUSKESMAS [13].

\subsection{MERS-CoV}

MERS-CoV stands for Middle East Respiratory Syndrome-Coronavirus. This virus is a new type of Coronavirus Group (Novel Coronavirus). The virus was first reported in March 2012 in Saudi Arabia. SARS virus is also a Coronavirus group and can cause severe pneumonia but differs from MERS-CoV. MERS-CoV is a respiratory syndrome disease caused by a coronavirus that attacks the respiratory tract ranging from mild to severe. The symptoms are fever, cough, and shortness of breath. Usually, the patient has the disease of morbid-ko. The median age was 49.5 years (range 2-94 years). 64\% of the cases are men. MERS-CoV has three levels of infection, i.e. the Stage 1, Stage 2, and Stage 3 [14].

\subsection{Dempster-shafer Method}

Dempster-Shafer theory was first introduced by Arthur P. Dempster and Glenn Shafer. This approach experimenting with uncertainty range probabilities rather than as a single probability. In the 1976, Shafer published the theory of Dempster in the book entitled Mathematical Theory of Evident. DempsterShafer theory is a mathematical theory of evidence. The approach can provide a way to combine the evidence 
from several sources and bring or give the trust level (represented through beliefs function) which took from all available evidence [15].

General writing of beliefs function and plausibility shown as follow:

- Belief $(\mathrm{Bel})$ is a measure of the strength of the evidence in support of a set of propositions. If Bel $=0$ then the value indicates that there is no evidence, and if $\mathrm{Bel}=1$ indicates the presence of certainty.

- Plausibility $(\mathrm{Pl})$ notation as $\mathrm{Pl}(\mathrm{s})=1-\mathrm{Bel}(-\mathrm{s})$. Plausibility value is also ranging from 0 to 1 . If we are sure $\ulcorner$ s, then it can be said that " $\operatorname{Bel}(-s)=0 "$ ".

On Dempster-Shafer theory, the frame of the decrement notation is $\theta$. This frame is the universe set from the set of hypothesis. The aim is to associate the size of trust elements of $\theta$. Not all of the evidence directly supporting each element. Therefore, the presence of the probability density function $(\mathrm{m})$ is necessary. The value of $\mathrm{m}$ is not only defining elements of $\theta$, but also all of its subsets. So if $\theta$ contains $n$ elements, then subset of $\theta$ is $2^{\mathrm{n}}$. The number of all $\mathrm{m}$ in subset of $\theta$ is equal to 1 . If there is no information to determine the hypothesis, then the value of $\mathrm{m}\{\theta\}=1.0$. If $\mathrm{X}$ is subset of $\theta$, with function of the density $\mathrm{m}_{1}$, and $\mathrm{Y}$ is also a subset of $\theta$ with function of the density $\mathrm{m}_{2}$, then the combination function of $\mathrm{m}_{1}$ and $\mathrm{m}_{2}$ shown in (1).

$$
m_{3}(Z)=\frac{\sum_{x \cap y=z} m_{1}(x) \cdot m_{2}(y)}{1-K}
$$

with $K=\sum_{x \cap y=\varnothing} m_{1}(x) \cdot m_{2}(y), K$ is total of evidential conflict.

\section{SYSTEM DESIGN}

\subsection{Expert Knowledge and Inference Engine}

There are two components in developing an expert system, i.e. expert knowledge and inference engine. The expert knowledge is made in the form of a disease decision table. Design of the disease decision table can be seen in Table 1. This decision table is obtained from pulmonary specialist, named Dr. Azizman Saad, Sp. P (K), FISR.

Table 1. The decision of the Disease based on symptoms and the value

\begin{tabular}{clcccc}
\hline Symptoms & \multicolumn{1}{c}{ Symptoms Name } & \multicolumn{2}{c}{ MERS-CoV Stage Level } & Density \\
\cline { 3 - 4 } Number & & St1 & St2 & St3 & Value (m) \\
\hline G1 & Dry cough & $\checkmark$ & & $\checkmark$ & 0.25 \\
G2 & Cough with phlegm & & $\checkmark$ & $\checkmark$ & 0.7 \\
G3 & Flu & $\checkmark$ & $\checkmark$ & & 0.4 \\
G4 & Severe flu & & & $\checkmark$ & 0.75 \\
G5 & Sore Throat & $\checkmark$ & & $\checkmark$ & 0.35 \\
G6 & Feel something stuck in throat & & $\checkmark$ & & 0.25 \\
G7 & Itchy throat & & $\checkmark$ & $\checkmark$ & 0.35 \\
G8 & Headache & & & $\checkmark$ & 0.4 \\
G9 & Chest tightness & & $\checkmark$ & $\checkmark$ & 0.9 \\
G10 & Returning from middle east in last 2 weeks & & $\checkmark$ & & 0.95 \\
G11 & Difficult to take a deep breath & & & $\checkmark$ & 0.3 \\
G12 & High heart rate & & $\checkmark$ & & 0.5 \\
G13 & During the day the body feels sick & $\checkmark$ & & 0.8 \\
G14 & Fever comes and goes & & $\checkmark$ & & 0.7 \\
G15 & Fever & & & $\checkmark$ & 0.95 \\
G16 & High fever (> 39 $9^{\circ}$ ) & & & 0.7 \\
G17 & Body temperature is high at night and low at day & $\checkmark$ & & &
\end{tabular}

The inference engine of the system applies the Dempster-Shafer approach. The inference engine used is explained by the following example. Suppose there are three symptoms felt by patients, i.e.: sore throat (G5), the chest tightness (G9), and fever (G15). Based on those cases, then the Dempster-Shafer method calculation is applied to get the largest possibility of the disease.

Step 1: First symptom is G5. G5 is symptom of MERS-CoV Stage 1 and Stage 3, thus $\mathrm{m}_{1}(\mathrm{St} 1$, St3) $=0.35$ and $m_{1}(\theta)=0.65$. The next symptom is G9. G9 is symptom of Stage 3 , thus $m_{2}($ St3 $)=0.9$ and $m_{2}(\theta)=0.1$. The cross multiplication between G5 and G9 is shown in Table 2. calculation of combination $\mathrm{m}_{1}$ and $\mathrm{m}_{2}$ resulting $\mathrm{m}_{3}$. 
Table 2. Combination of $\mathrm{m}_{1}$ and $\mathrm{m}_{2}$

\begin{tabular}{lcc}
\hline \multicolumn{1}{c}{$\mathrm{m}_{1} / \mathrm{m}_{2}$} & $\mathrm{~m}_{2}(\mathrm{St} 3)=0.9$ & $\mathrm{~m}_{2}(\Theta)=0.1$ \\
\hline $\mathrm{m}_{1}(\mathrm{St} 1, \mathrm{St} 3)=0.35$ & $0.315(\mathrm{St} 3)$ & $0.035(\mathrm{St} 1, \mathrm{St} 3)$ \\
$\mathrm{m}_{1}(\Theta)=0.65$ & $0.585(\mathrm{St} 3)$ & $0.065(\Theta)$ \\
\hline
\end{tabular}

Result of the combinations are:

$\begin{array}{ll}\mathrm{K} & =1, \text { such that } 1-\mathrm{K}=1-0=1 \\ \mathrm{~m}_{3}(\mathrm{St} 1, \mathrm{St} 3) & =0.035 / 1=0.035 \\ \mathrm{~m}_{3}(\mathrm{St} 3) & =(0.315+0.585) / 1=0.9 \\ \mathrm{~m}_{3}(\Theta) & =0.065 / 1=0.065\end{array}$

Step 2: Third symptom is G15. G15 is symptom of MERS-CoV Stage 2, thus $\mathrm{m}_{4}(\mathrm{St} 2)=0.7$ and $\mathrm{m}_{4}(\theta)=0.3$. The cross multiplication between the result of step 1 and G15 as shown in Table 3, calculate combination of $\mathrm{m}_{3}$ and $\mathrm{m}_{4}$ as $\mathrm{m}_{5}$ :

Table 3. Combination of $\mathrm{m}_{3}$ and $\mathrm{m}_{4}$

\begin{tabular}{lcc}
\hline \multicolumn{1}{c}{$\mathrm{m}_{3} / \mathrm{m}_{4}$} & $\mathrm{~m}_{4}(\mathrm{St} 2)=0.7$ & $\mathrm{~m}_{4}(\Theta)=0.3$ \\
\hline $\mathrm{m}_{3}(\mathrm{St} 1, \mathrm{St} 3)=0.035$ & $0.0245(\mathrm{~K})$ & $0.0105(\mathrm{St} 1, \mathrm{St} 3)$ \\
$\mathrm{m}_{3}(\mathrm{St} 3)=0.9$ & $0.63(\mathrm{~K})$ & $0.27(\mathrm{St} 3)$ \\
$\mathrm{m}_{3}(\Theta)=0.065$ & $0.0455(\mathrm{St} 2)$ & $0.0195(\Theta)$ \\
\hline
\end{tabular}

Result of the combinations are:

$$
\begin{array}{ll}
\mathrm{K} & =0.0245+0.63=0.6545, \text { such that } 1-\mathrm{K}=0.3455 \\
\mathrm{~m}_{5}(\mathrm{St} 1, \mathrm{St} 3) & =0.0105 / 0.3455=0.0304 \\
\mathrm{~m}_{5}(\mathrm{St} 2) & =0.0455 / 0.3455=0.1317 \\
\mathrm{~m}_{5}(\mathrm{St} 3) & =0.27 / 0.3455=0.7814 \\
\mathrm{~m}_{5}(\Theta) & =0.0195 / 0.3455=0.0564
\end{array}
$$

Step 3: As all symptoms are combined, the last step is to make a conclusion. Based on the calculation, the highest probability results are St3 (Stage 3) with a value of 0.7814 or $78.14 \%$. Then, the patient is suspected of having a stage 3 MERS-CoV with level of belief $78.14 \%$.

\subsection{Use Case Diagram}

Figure 1. is use case diagram of the expert system. There are two actors in this system, i.e. the visitors and admin. Visitors can see the disease information, see guidelines and make the diagnosis. While admins can manage knowledge base, view diagnosis history, manage symptoms, manage the disease, manage accounts, and manage patients.

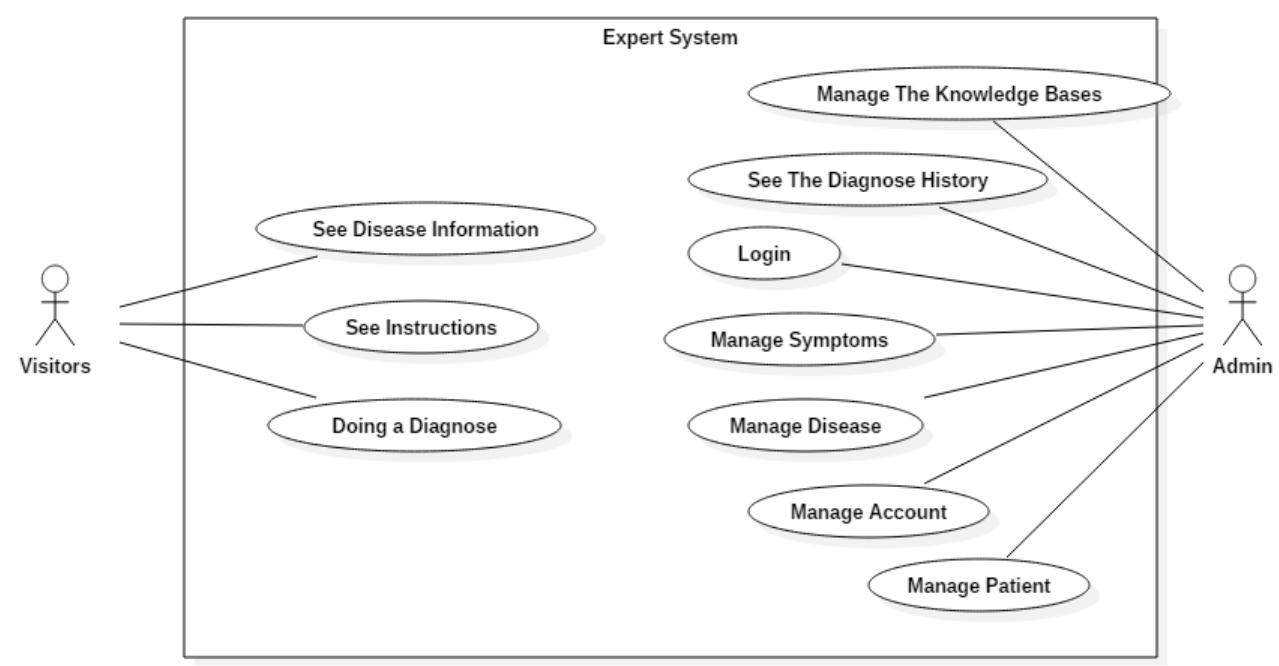

Figure 1. Use case diagram 


\section{RESULT AND ANALYSIS}

\subsection{Implementation of Dempster-method in Web Application Expert System}

Figure 2. is the home page of this expert system. This page displays information and videos about MERS-CoV. In the first page, there is information about MERS-CoV. If visitors want to diagnose the disease, there is diagnosis button that will redirect to diagnosis page. Visitors can also change the language of the website as they desire by selecting the menu contained at the top right. Figure 3. is a diagnostic page contains symptoms which the visitors select. In this page, visitors will do a diagnosis where visitors will choose the symptoms that they have, then pressing the diagnose button to see the diagnosis result.

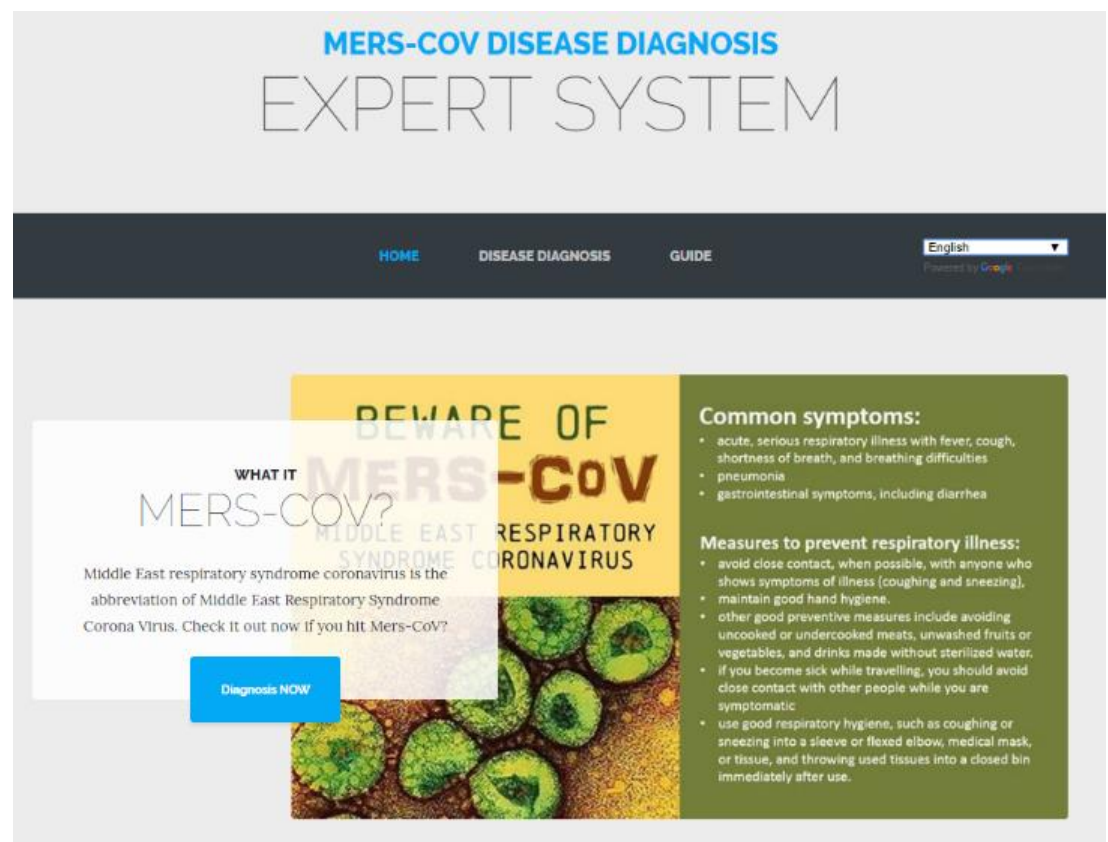

Figure 2. Front page interface

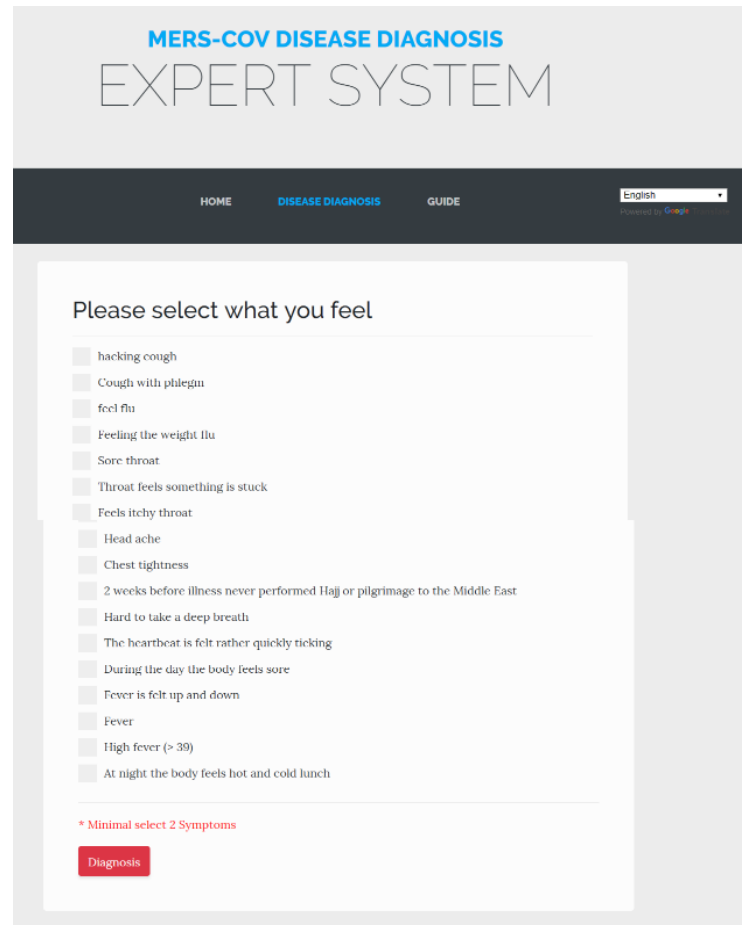

Figure 3. Diagnosis interface 
Figure 4. is the result page of the diagnosis process in diagnosis page. This page displays the result of possible disease, description and the symptoms selected by the visitors in previous page. On this page the result obtained from the process of Dempster-Shafer method from the selected symptoms by the previous visitors so that the issuing of the results in the form of a disease that is detected and the value of the probability of the trust.

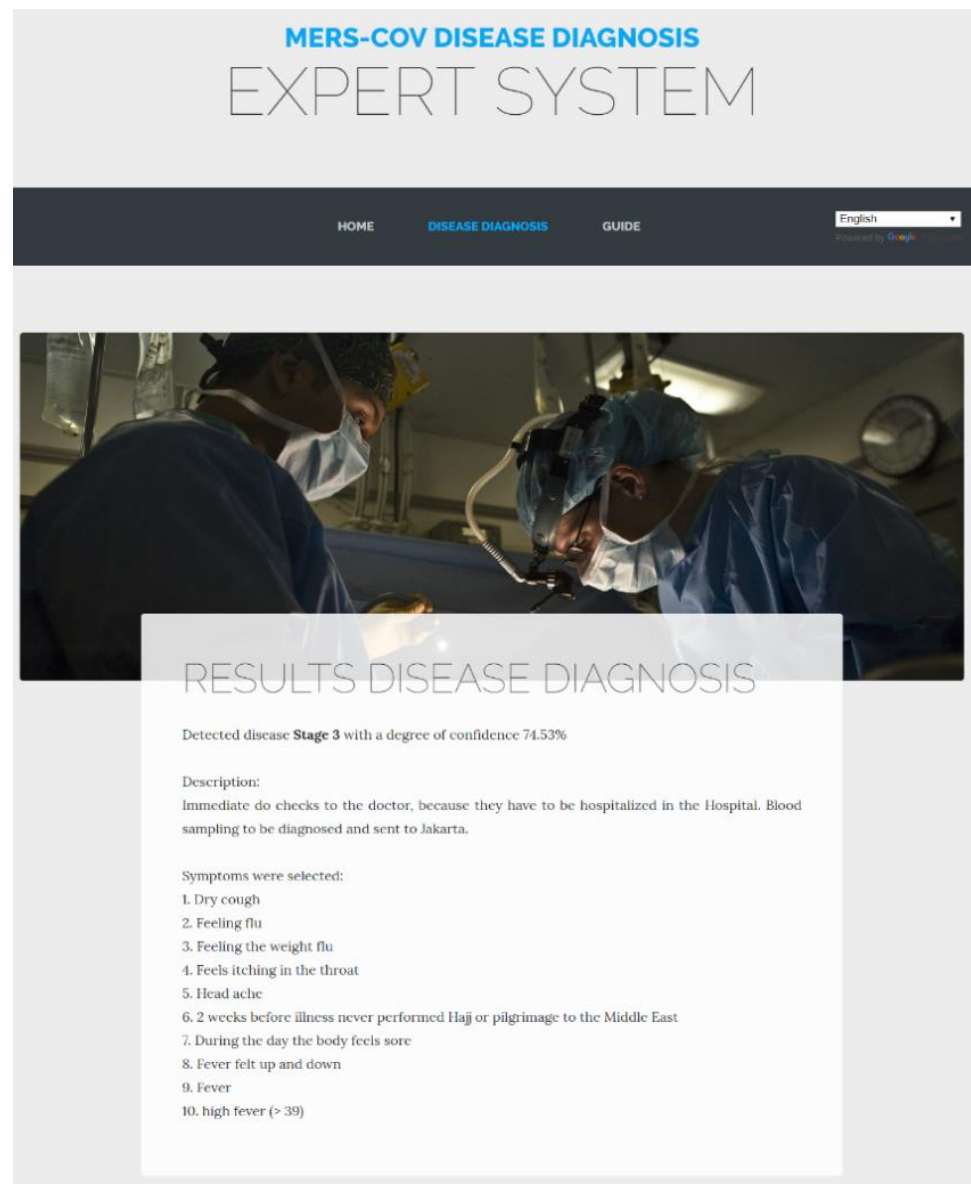

Figure 4. Diagnosis result interface

\subsection{Control Flow Testing}

Based on the result of white box testing to the Dempster-Shafer method, obtained 20 edges and 14 nodes, thus the cyclomatic complexity calculated value is 8 . Based on the value of the methods used in the range of 1 to 10, it shows that the program code Dempster-Shafer algorithm that is used pertained to simple and less risk program. Control flow graph of the source code shown in Figure 5.

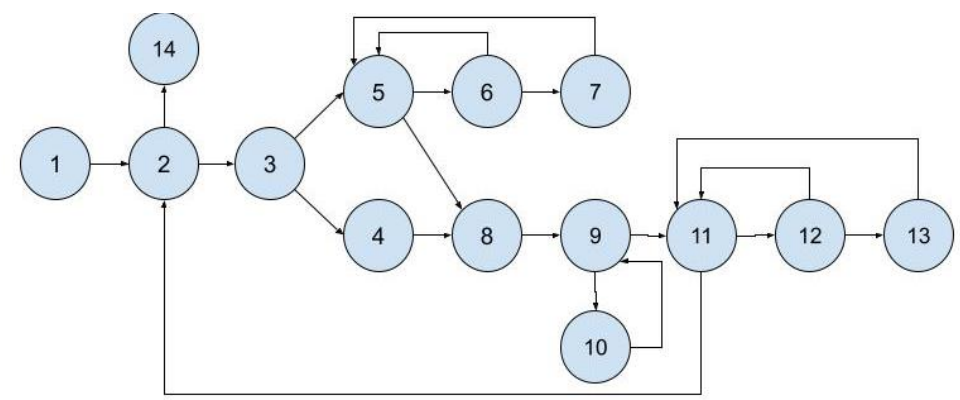

Figure 5. Control flow graph 


\subsection{Expert Validation Testing}

Based on the results of accuracy testing by comparing the results of the expert system diagnosis and the doctor's analysis. From a total of 30 cases in the test cases, 23 cases have the same diagnosis results as the results of the analysis carried out by the experts, therefore the system accuracy is $76.7 \%$. Seven cases tested have different results between the system diagnosis and expert analysis. 6 of 7 misdiagnosis occurred between stage 2 and stage 3. Some expert validation test cases are shown in Table 4.

Table 4. Some expert validation test cases

\begin{tabular}{|c|c|c|c|c|}
\hline No & Symptoms Inputed & $\begin{array}{c}\text { System Diagnosis } \\
\text { Results }\end{array}$ & $\begin{array}{c}\text { Expert Diagnosis } \\
\text { Results } \\
\end{array}$ & $\begin{array}{c}\text { Valid / No } \\
\text { Valid } \\
\end{array}$ \\
\hline 1 & $\begin{array}{l}\text { 1. Dry cough } \\
\text { 2. Flu } \\
\text { 3. Sore throat } \\
\text { 4. Headache } \\
\text { 5. Chest tightness }\end{array}$ & $\begin{array}{l}\text { Stage } 3 \\
87.42 \%\end{array}$ & Stage 2 & - \\
\hline 2 & $\begin{array}{l}\text { 1. Cough phlegm } \\
\text { 2. Severe flu } \\
\text { 3. Feel something stuck in throat } \\
\text { 4. Itchy throat } \\
\text { 5. Fever } \\
\text { 6. Bodv temperature is high at night and low at dav. }\end{array}$ & $\begin{array}{l}\text { Stage } 3 \\
50.05 \%\end{array}$ & Stage 3 & $\sqrt{ }$ \\
\hline 3 & $\begin{array}{l}\text { 1. Feel something stuck in throat } \\
\text { 2. Not performed hajj or umrah nor returning from } \\
\text { middle east in last } 2 \text { weeks } \\
\text { 3. Hard to take deep breath } \\
\text { 4. Fever come and go } \\
\text { 5. High fever }\left(>39^{\circ} \mathrm{C}\right) \\
\text { 6. Body temperature is high at night and low at dav }\end{array}$ & $\begin{array}{l}\text { Stage } 2 \\
66.62 \%\end{array}$ & Stage 3 & - \\
\hline 4 & $\begin{array}{l}\text { 1. Cough phlegm } \\
\text { 2. Feel flu } \\
\text { 3. Chest tightness } \\
\text { 4. Hard to take deep breath } \\
\text { 5. Body is unfit at noon } \\
\text { 6. Fever come and go }\end{array}$ & $\begin{array}{l}\text { Stage } 2 \\
89.84 \%\end{array}$ & Stage 2 & $\sqrt{ }$ \\
\hline 5 & $\begin{array}{l}\text { 1. Dry cough } \\
\text { 2. Feel flu } \\
\text { 3. Sore throat } \\
\text { 4. Fever come and go } \\
\text { 5. Body temperature is high at night and low at day }\end{array}$ & $\begin{array}{l}\text { Stage 1 } \\
83.53 \%\end{array}$ & Stage 1 & $\sqrt{ }$ \\
\hline 6 & $\begin{array}{l}\text { 1. Cough phlegm } \\
\text { 2. Feeling the severe flu } \\
\text { 3. Sore throat } \\
\text { 4. Fever is come and go } \\
\text { 5. Body temperature is high at night and low at day }\end{array}$ & $\begin{array}{c}\text { Stadium } 1 \\
37.26 \%\end{array}$ & Stage 2 & - \\
\hline
\end{tabular}

\subsection{Questionnaire Testing}

From the results of testing questionnaires with the users, $84.13 \%$ of users strongly agreed that the overall system helps patients to diagnose Mers-CoV with the Dempster-Shafer method. With the average results of the questionnaire, it shows that it is classified as a very good criterion.

\section{CONCLUSION}

The conclusions of this study are: The web-based expert system for diagnosing MERS-CoV disease using the Dempster-Shafer method has been successfully built with general symptoms input. The DempsterShafer method that is implemented in an expert system run as the way Dempster-Shafer method actually works. Thus, the Dempster-Shafer method is successfully implemented in the expert system for diagnosing MERS-CoV disease. Based on the results of the Black Box test, the expert system for diagnosing MERS$\mathrm{CoV}$ disease is running as expected functionality. Based on the result of the white box testing to DempsterShafer program, the result of cyclomatic complexity value is 8 , so that it is classified into a simple program code with less risks, therefore the program code is easily maintained and suitable to be implemented on the system. Based on the result of the questionnaire testing, an average score of respondents $84.13 \%$ of users agree that the system can help users in diagnosing Mers-CoV disease. Based on the results of expert validation testing the value of system accuracy is $76.7 \%$ which indicates that this expert system is functioning properly. The inaccuracy of expert systems is $23.3 \%$, this is due to errors in the value of trust in a symptom is very influential in the process of calculating methods to get the results. 


\section{REFERENCES}

[1] WHO, "WHO | Middle East respiratory syndrome coronavirus (MERS-CoV)," WHO, 2019.

[2] T. Masduki, "Berapa Jemaah Umrah dari Indonesia?," katadata, 2017. [Online]. Available: https://databoks.katadata.co.id/datapublish/2017/03/03/berapa-jamaah-Umrah-indonesia. [Accessed: 18-Apr-2018].

[3] L. Handayani and T. Sutikno, "Sistem Pakar untuk Diagnosis Penyakit Hati Berbasis Web dengan ' e2gLite Expert System Shell ,"” System, 2012, pp. 63-70.

[4] Y. N. Istiqomah and A. Fadlil, "Sistem pakar untuk mendiagnosa penyakit saluran pencernaan menggunakan metode dempster shafer 1," J. Sarj. Tek. Inform. Vol. 1 Nomor 1, Juni 2013 e-ISSN 2338-5197, vol. 1, pp. 32-41, 2013.

[5] M. Dahria, R. Silalahi, and M. Ramadhan, "Sistem Pakar Metode Dempster-Shafer untuk Menentukan Jenis Gangguan Perkembangan pada Anak", Jurnal Ilmiah Saintikom, vol. 12, no. 1, Januari 2013

[6] D. A. Kusuma and C. Chairani, "Rancang Bangun Sistem Pakar Pendiagnosa Penyakit Paru-Paru Menggunakan Metode Case Based Reasoning," J. Inform. dan Elektron., vol. 6, no. 2, pp. 57-62, 2015.

[7] L. S. Lesmana, "Sistem Pakar Dengan Metode Forward Chaining Untuk Diagnosa Pasien Yang Terinfeksi Virus Mers Cov ( Studi Kasus Di RSUP M.Djamil Padang)," CBIS Journal, Vol. 3 No 2, ISSN 2337-8794, vol. 3, no. 2 , pp. 49-65, 2015.

[8] M. Marlina, W. Saputra, B. Mulyadi, B. Hayati, and Jaroji, "Aplikasi Sistem Pakar Diagnosis Penyakit ISPA Berbasis Speech Recognition Menggunakan Metode Naive Bayes,” Teknol. Inf. dan Komun. Digit. Zo., vol. 8, no. 1, pp. 58-70, 2017.

[9] R. D. M. Badriyah, and A. Ariyani, "Sistem Pakar Untuk Diagnosa Penyakit Paru - Paru Menggunakan Metode Certainty Factor Di Puskesmas Citangkil,” J. ProTekinfo, vol. 4, pp. 34-42, 2017.

[10] B. Yong and L. Owen, "Model Penyebaran Penyakit Menular MERS-CoV: Suatu Langkah Antisipasi untuk Calon Jamaah Haji/Umrah Indonesia", Lembaga Penelitian dan Pengabdian Masyarakat, Universitas Katolik Parahyangan, Bandung, 2015

[11] N. Zang, S. Jiang, and L. Du, "Current advancements and potential strategies in the development of MERS-CoV vaccines", Expert Review of Vaccines, vol. 13, no. 6, pp. 761-776, April 2014

[12] H. Momattin, K. Mohammed, A. Zumla, Z. A. Memish and J. A. Al-Tawfiq, "Therapeutic Options fo MERS-CoV possible lessons from a systematic review SARS-CoV therapy", Internationa Journal of InfectiousDisease, vol. 17, no. 10, pp. e792-2798, 2013

[13] R. Djoge and K. Hasan, "Diagnosa Penyakit AIDS, MERS Virus dan Ebola Berbasis Web di Puskesmas Siko Ternate", Indonesian Journal on Information System, vol. 3, no. 1, pp. 1-9, April 2018.

[14] M. East and R. S. Virus, "Pedoman Umum Kesiapsiagaan Menghadapi (MERS-CoV)," 2013.

[15] D. P. Kurniawati, "Implementasi Metode Dempster Shafer Pada Sistem Pakar Untuk Diagnosa Jenis-jenis Penyakit Diabetes Melitus," Psi Udinus, 2014. 